ЕНЕРГЕТИКА

ТЕПЛОТЕХНІКА

ЕЛЕКТРОТЕХНІКА

ENERGETICS

HEAT ENGINEERING

ELECTRICAL ENGINEERING

UDC 621.039.56

M.V. Maksimov, Dr.Eng., Professor,

N.F. Kanazirskyi, Master,

E.A. Kokol, Master,

Odessa National Polytechnic University

\title{
CONTROL OF THE AXIAL OFFSET IN A NUCLEAR REACTOR AT POWER MANEUVERING
}

Introduction. Currently the nuclear share in the power generation in Ukraine constitutes about $50 \%$, while the total installed capacity of NPPs is $13.8 \mathrm{GW}$. According to the Energy Strategy of Ukraine for the period up to 2030, the installed capacity of NPPs will be near $25 \mathrm{GW}$ [1].

The Ukrainian NPPs are designed to operate in the basic part of the schedule of electric loading, while the share of basic energy consumers in the country is much smaller than $50 \%$. An increase of the nuclear share in the power generation of Ukraine will result in the need for operation of NPPs in the semi-peak part of the electric load schedule, instead of the basic part. Ideally, the schedule of nuclear power generation should correspond to the consumption map of a power supply system. Therefore operation of the nuclear blocks with VVER in the variable mode has become an actual task for the power supply system of Ukraine.

A nuclear reactor is the source of enhanced danger. One of the requirements for safe reactor operation is the energy release uniformity in the reactor core. Based on this, one of the most important tasks is maintenance of the energy release uniformity which is a guarantee of reactor operation stability, reliable and safe operation of the equipment, as well as favourable operating conditions for nuclear fuel and rod-type fuel elements in stationary and maneuvering modes of reactor operation [2].

Analysis of recent research and publications. The references' analysis showed that among series of the possible solutions applicable to the problem of power unit control in maneuvering mode, the automated test equipment (ATE) improving is this one of the highest priority.

Every change in reactor core condition or its energy release scheme does involve the problem of reactor stability and reliability caused by the xenon transient phenomena with positive feedback [2]. The multiple changes in reactor core energy release occurring during power maneuvering can lead to

DOI 10.15276/opu.2.44.2014.15

(C) M.V. Maksimov, N.F. Kanazirskyi, E.A. Kokol, 2014

ЕНЕРГЕТИКА. ТЕПЛОТЕХНІКА. ЕЛЕКТРОТЕХНІКА 
the fuel cells' rapid wear and reliability decrease or to stress tensions in some areas of the rod-type fuel elements $[3,4]$. The daily increase in efficiency of nuclear fuel use and its burn-up fraction does lead to neutron fields' stability decreasing and consequently to energy release stability drop with reactor core condition stability deterioration.

During the steady-state operation of reactor the WWER-1000 power distribution standard automated control system is fairly efficient in suppressing small variations due to the accumulation of xenon $\left({ }^{135} \mathrm{Xe}\right)$. However, at reactor power maneuvering from one level to another we do observe some xenon instability or xenon fluctuations that affect the changes in energy release distribution at reactor core [5].

There exist various methods to maintain a stable energy release, however the xenon fluctuations problem at different automated control systems and their programs applied remains still open as each control program differently influences the energy release.

Research objective. The research is aimed onto the axial offset concept definition, investigation of WWER-1000 power unit different static regulatory programs influence, elaborating techniques to maintain an optimal axial offset of power unit in maneuvering mode, adjusting settings of neutron power regulator and its integration into compromise-combined power unit regulation system.

Present research exposition. The quantitative measure of energy release uniformity along the reactor core vertical projection is represented with a special integral parameter, the axial offset (AO), therefore the power unit's effective operation does imply the necessity to minimize AO deviations. The $\mathrm{AO}$ value is defined as the difference in energy release between the reactor core upper and lower parts referred to the total energy release [6].

$$
\mathrm{AO}=\frac{Q_{T}-Q_{B}}{Q_{T}+Q_{B}} 100 \%,
$$

where $Q_{T}$ - thermal energy in the upper half of the core, MW;

$Q_{B}$ - thermal energy in the lower half of the core, MW.

To identify AO during reactor operation we can use several methods. E.g. we can observe the reactor core top section's neutron flux lowering with the use of information technology equipment, which receives signals from neutron detectors. Also, the AO present or approaching can be detected by chemical diagnostics.

In maneuvering mode, the $\mathrm{AO}$ should be maintained in accordance with the established standard range depending on the current power level (Fig. 1).

$\mathrm{AO}$ value shifting beyond the permissible values can involve an uneven neutron flux thus the axial xenon oscillations emerging, that have a negative impact on the reactor and $1^{\text {st }}$ loop equipment stabilization time. Under certain conditions, the unevenness of the neutron flux in the reactor core can lead to pre-emergency or emergency situations.

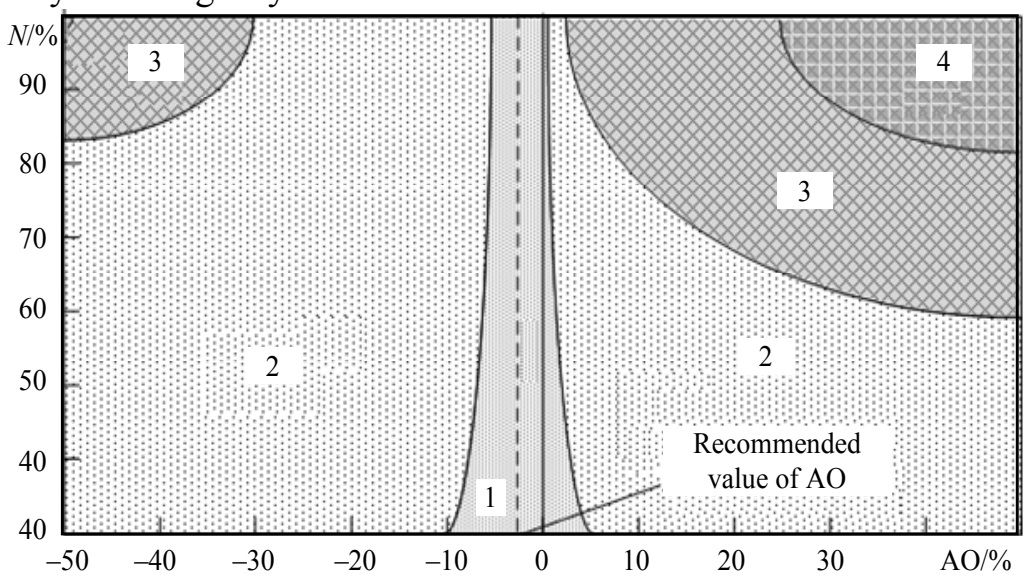

Fig. 1. Standard routine range of AO values, depending on the reactor power level: 1 - recommended area; 2 - acceptable area; 3 - not recommended area; 4 - excluded area 
Power maneuvering is carried out according to static control programs, which represent the dependence of power unit process parameters onto the produced capacity at steady-state conditions. Therefore we need to consider how process parameters' changes in the known static control programs do affect the $\mathrm{AO}$ in maneuvering modes.

In practice of nuclear power plants operation the following main static regulation programs of the WWER-1000 power unit are applied [7]:

1) I program - the control program maintaining a constant average temperature of the reactor core coolant;

2) II program - the control program maintaining a constant pressure in the second loop and hence a constant temperature of saturated steam in the $2^{\text {nd }}$ loop;

3) III program - the compromise control program providing a moderate change in the average temperature of the reactor core coolant and in the $2^{\text {nd }}$ loop pressure;

4) IV program - the combined program maintaining a constant pressure in the $2^{\text {nd }}$ loop at low loads and a constant average temperature of the reactor core coolant at high loads.

There was offered a power unit capacity control program that involves maintaining the steady $\mathrm{AO}$ value when transferring the power unit from one level to another.

To ensure stability of the reactor core bottom half it is necessary to maintain the constant coolant temperature at the reactor core inlet. This constant coolant temperature level is achieved by controlling the steam pressure in the steam generator by changing the turbine control valves position.

Also the constant $\mathrm{AO}$ value is maintained by changing the control rods $(\mathrm{CR})$ group position in the reactor top half.

The main distinctive feature between this control program and the others is that the reactor core inlet $1^{\text {st }}$ loop coolant temperature is maintained constant one by regulating the steam pressure in the steam generator through changes in the turbine control valves' position.

The control algorithm that implements a compromise-combined control program (Fig. 2), does follow a specific sequence [7]. At the power system request to reduce the reactor plant power unit the operator commands to enter the required amount of boric acid in the $1^{\text {st }}$ loop coolant for changing the power unit capacity. The boric acid solution is progressively added/removed (by adding the desalted water) through the boost pumps' tank 17 to the coolant at an assigned standard speed.

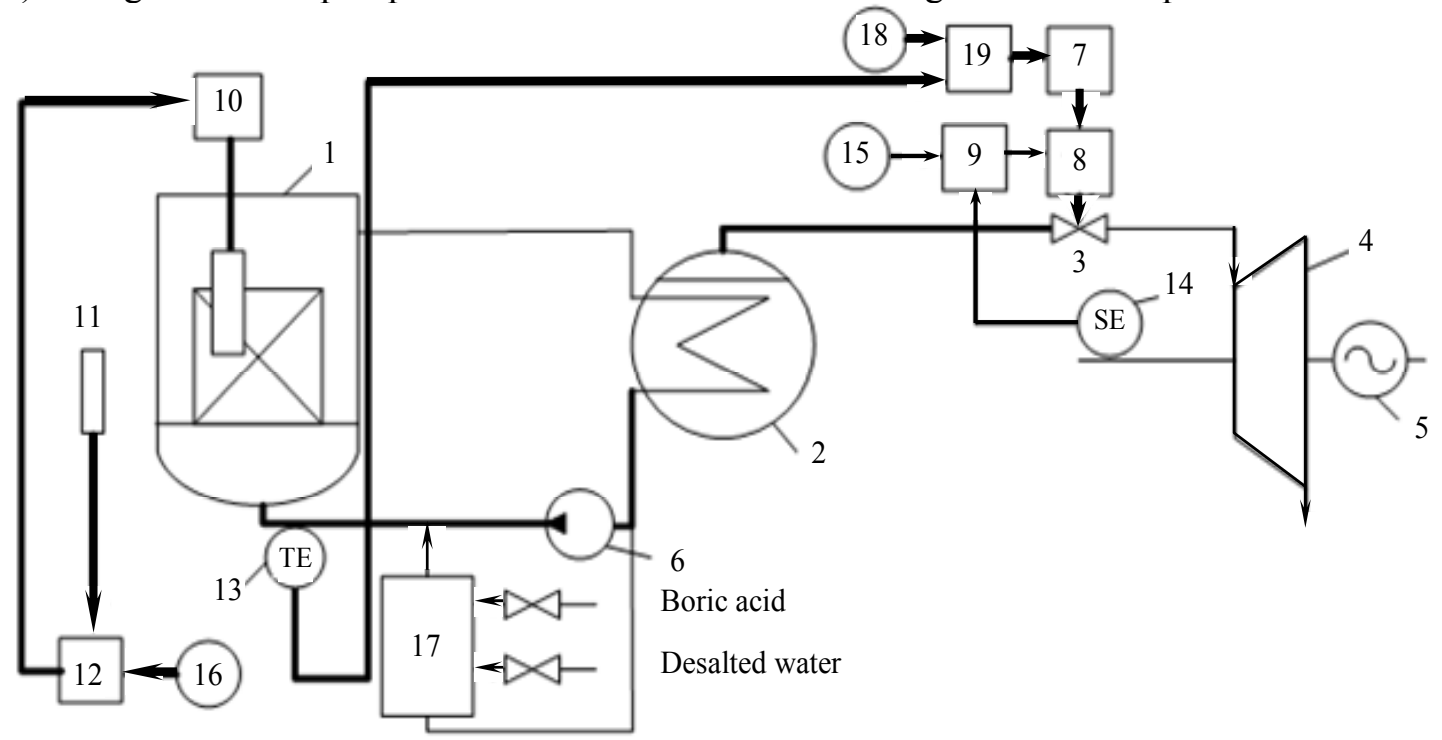

Fig. 2. Schematic diagram of the control units with WWER-1000, which implements a compromise-combined ATE

The reactor core bottom half does not contain control rods and the main disturbance therein occurring relates to changes in the reactor core inlet coolant temperature. 
Therefore in order to stabilize the reactor core bottom half it is necessary to maintain constant coolant temperature at the reactor core inlet. The reactor core coolant temperature regulator 19 does generate the control action by comparing the given 18 and the actual 13 coolant temperature values at the reactor core inlet. This action influences further the turbine control mechanism 7 and control gear 8 repositioning the control valves 3 of turbine 4 .

At that, the neutron power controller 12 generates control action applied to the control rods regulatory group's 10 control rods drive by comparing the given 16 and the actual $11 \mathrm{AO}$ values.

Thus, the advanced ATE specific feature represents a new control loop where the reactor core inlet constant coolant temperature is maintained by regulating the steam pressure in the steam generator.

In addition, the advanced ATE peculiarity relates to another new offset control loop, where the constant value of AO is maintained by moving the CR group [7]. To adjust this loop, it is necessary to calculate the neutron power controller settings, regulated by the proportional-plus-integral (PI) action control principle. Controller settings calculations are performed by the method of A. Kopelovich.

For the neutron power controller setting we created a step disturbance $\Delta M$ by entering $10 \%$ $(35,35 \mathrm{~cm})$ of CR group in the reactor core.

The step function response curve for "CR group reactivity - AO" channel appears as:

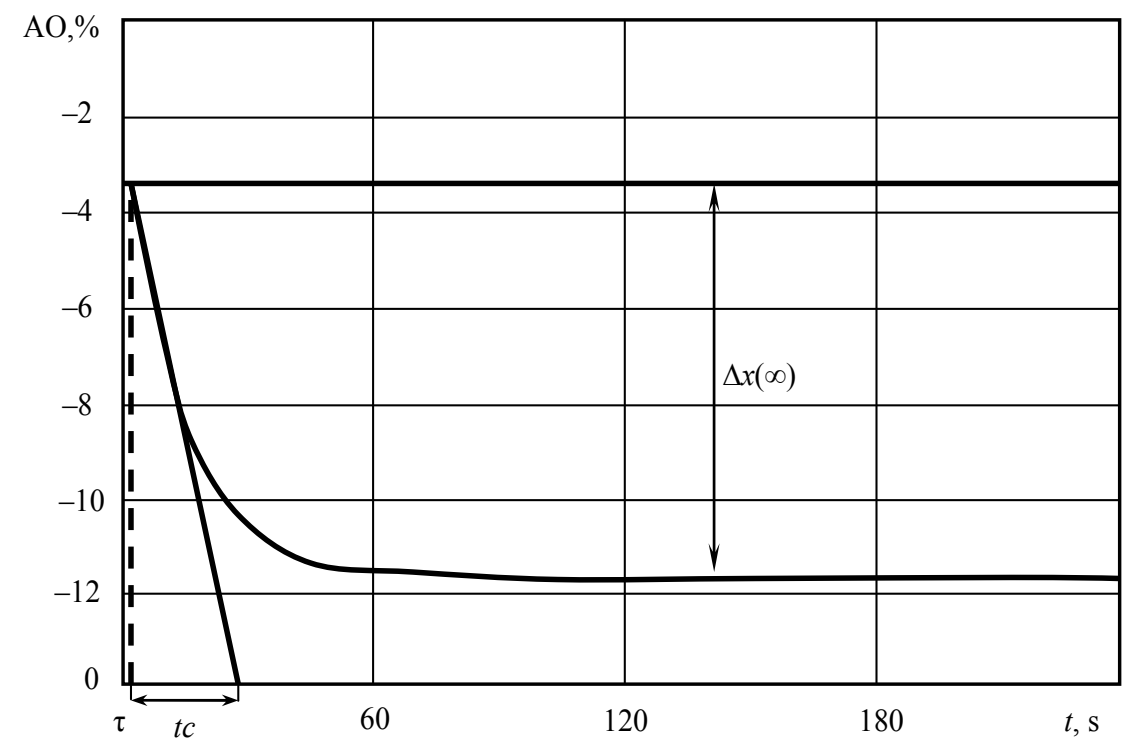

Fig. 3. Ramp at channel " $C R$ group reactivity - AO”

The response curve shown at Fig. 3 has been processed by the standard method. As a result we did find: full time delay $\tau=2 s$; AO value deviation when steady state $\Delta x(\infty)=-8,2 \%$ and object transfer constant $k=\frac{\Delta x(\infty)}{\Delta M}=0,232 \% / \mathrm{cm}$.

Considering the aforesaid, the transfer coefficient and the integration time are calculated as follows:

$$
\begin{gathered}
K_{T}=\frac{0,6}{k \cdot \tau / T a}=\frac{0,6 \cdot 29}{0,232 \cdot 3}=37,5 \mathrm{~cm} / \%, \\
K_{T}=\frac{0,6}{k \cdot \tau / T a}=\frac{0,6 \cdot 29}{0,232 \cdot 3}=37,5 \mathrm{~cm} / \%, \\
T_{I}=0,6 \cdot T a=17,4 \mathrm{~s} .
\end{gathered}
$$

With such a transfer coefficient when step disturbance applied by reducing steam consumption for $40 \mathrm{~kg} / \mathrm{s}$, the transient process has the form (Fig. 4) 


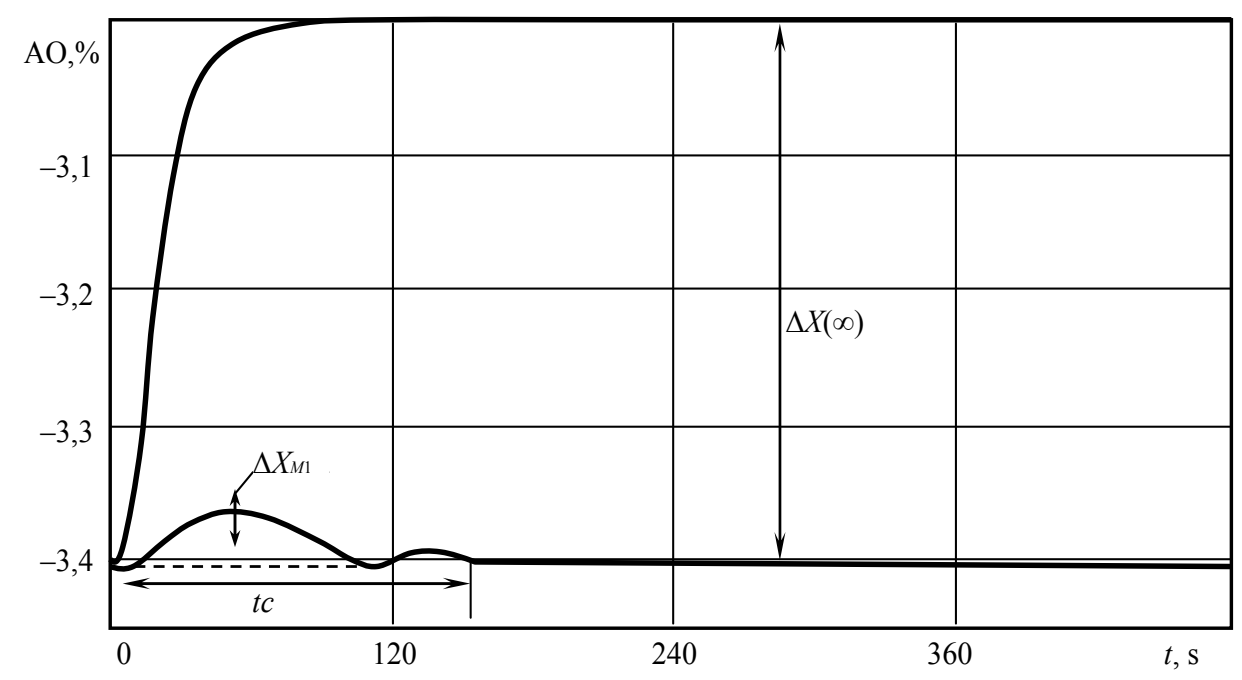

Fig. 4. Transient when step disturbance applied by steam consumption

The transient phenomenon quality can be estimated by the chart using direct quality indexes:

1. The first maximum of axial offset deviation $\Delta X_{M 1}=0,05 \%$.

2. The third maximum of axial offset deviation $\Delta X_{M 3}=0,003 \%$.

3. Control time $t_{c}=150 \mathrm{~s}$.

4. Deviation of axial offset in the absence of controller $\Delta X(\infty)=0,4 \%$.

Apart of direct transients quality indexes there exist some indexes found through calculation:

5. Degree of damping $\psi=\frac{\Delta X_{M 1}-\Delta X_{M 3}}{\Delta X_{M 1}}=0,94$. Degree of damping is satisfactory when $\psi=0,75 \ldots 0,95$.

6. Dynamic control coefficient $R d=\frac{\Delta X_{M 1}}{\Delta X(\infty)}=0,1$ that shows efficiency of the controlling regulator's compensating action onto the object.

Results. The power unit operating at designed power level the regulation program doesn't play an important role. However the maneuvering modes regulation program choice can have an essential impact on the power unit characteristics and its equipment further operation.

It is revealed that any control program doesn't maintain AO stability in power maneuvering mode, that implies a necessity to create an improved ATE, maintaining AO unchanged in the maneuvering mode that will ensure the reactor and power unit stability. As a result of such ATE use, we calculated the design parameters of a neutron power controller, integrated in the reactor compromise-combined power control system (Fig. 5) implemented with the use Simulink (MATLAB program pack).

Conclusions. Analyzing the WWER-1000 equipped NPP power unit as control object we observed that one of the most important problems of power unit operation relates to maintaining an uniform power distribution in the reactor core in the axial direction as a guarantee of the reactor stability.

The known control programs' process variables changes impact on AO in maneuvering mode has been analyzed. It is shown that all known control programs in maneuvering mode do involve the AO value alternation that may cause xenon oscillations and hence the reactor stability loss.

The compromise-combined control method investigated, we assessed its main difference from the known methods, consisting in constant coolant temperature at the reactor inlet maintenance using the steam pressure variation by repositioning the turbine valves. Maintaining the reactor core inlet coolant constant temperature allowed us to stabilize the reactor core bottom part, that has an evidently positive effect onto AO control. 


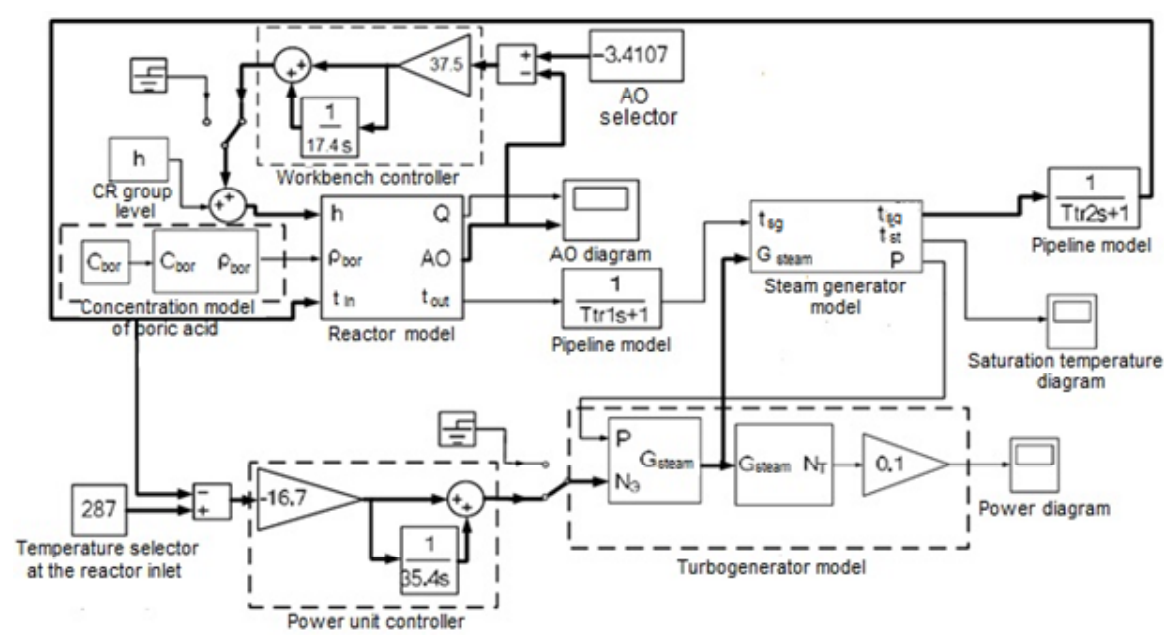

Fig. 5. Power unit advanced ATE simulation model

The result of axial offset adjusting with the use of improved ATE is shown at Fig. 6.

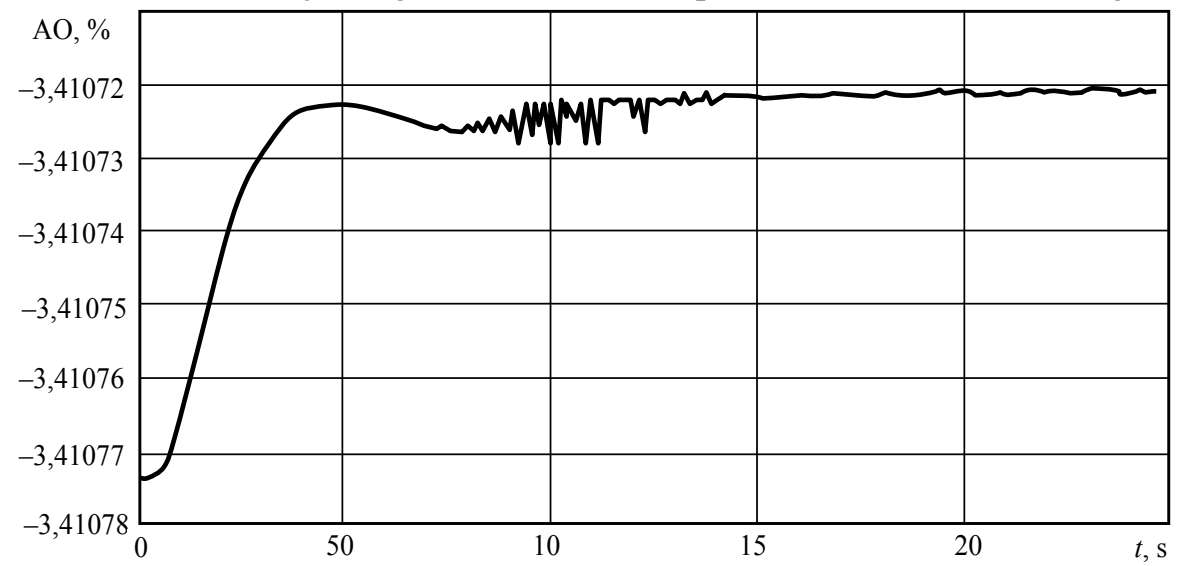

Fig. 6. Axial offset transient process regulation at WWER-1000

The neutron power controller settings are calculated by the method of A. Kopelovich. Analyzing the quality indexes values we conclude that the quality of control using the obtained PI controller settings does satisfy the problem solution.

\section{Література}

1. Гелетуха, Г.Г. Анализ основных положений “Энергетической стратегии Украины на период до 2030 года" / Г.Г. Гелетуха, Т.А. Железная // Пром. теплотехника. — 2006. — Т. 28, № 5. - С. 82 92.

2. Blok, J. Modeling the axial offset anomaly in PWRs / Blok, J.\& Chauffiriat, S.\& Frattini, P. // Proc. Int. Conf. on Water Chemistry of Nuclear Reactor Systems, 21-25 April, 2002, Avignon, France.

3. Maksimov, M.V. Principles of controlling fuel-element cladding lifetime in variable VVER-1000 loading regimes / M.V. Maksimov, S.N. Pelykh, R.L. Gontar // Atomic Energy. — 2012. — Vol. 112, No. 4. - PP. $241-249$.

4. Pelykh, S.N. Cladding rupture life control methods for a power-cycling WWER-1000 nuclear unit / S.N. Pelykh, M.V. Maksimov // Nuclear Engineering and Design. - 2011. — Vol. 241, Issue 8. PP. $2956-2963$.

5. Deswandri. Application of Three Axial Offsets Trajectory Method for Load Follow Operation Control in PWRs / Deswandri, Y. Shimazu // Journal of Nuclear Science and Technology. — 2001. — Vol. 38, Issue 10. - PP. $809-818$.

6. Deshon, J. PWR Axial Offset Anomaly (AOA) Guidelines, Revision 1 / J. Deshon. —EPRI: Palo Alto, CA, 2004. 
7. Maksimov, M.V. A model of a power unit with VVER-1000 as an object of power control / M.V. Maksimov, K.V. Beglov, T.A. Tsiselskaya // Пр. Одес. політехн. ун-ту. — 2012. — Вип. 1(38). — PP. $99-106$.

\section{References}

1. Geletukha, G. and Zhelyezna, T. (2006). Analysis of main provisions of "Energy strategy of Ukraine for the period till 2030". Industrial Heat Engineering, 28(5), 82-92.

2. Blok, J., Chauffiriat, S. and Frattini, P. (2002). Modeling the axial offset anomaly in PWRs. In Proceedings of International Conference on Water Chemistry of Nuclear Reactor Systems - Operation Optimisation and New Developments. Avignon, France: Societe Francaise d'Energie Nucleaire.

3. Maksimov, M.V., Pelykh, S.N. and Gontar, R.L. (2012). Principles of controlling fuel-element cladding lifetime in variable VVER-1000 loading regimes. Atomic Energy, 112(4), 241-249.

4. Pelykh, S.N. and Maksimov, M.V. (2011). Cladding rupture life control methods for a power-cycling WWER-1000 nuclear unit. Nuclear Engineering and Design, 241(8), 2956-2963.

5. Deswandri and Shimazu, Y. (2001). Application of three axial offsets trajectory method for load follow operation control in PWRs. Journal of Nuclear Science and Technology, 38(10), 809-818.

6. Deshon, J. (2004). PWR Axial Offset Anomaly (AOA) Guidelines, Revision 1. Palo Alto, CA: EPRI.

7. Maksimov, M.V., Beglov, K.V. and Tsiselskaya, T.A. (2012). A model of a power unit with VVER1000 as an object of power control. Odes 'kyi Politechnichnyi Universytet. Pratsi, 1, 99-106.

\section{АНОТАЦЯ / АННОТАЦИЯ / ABSTRACT}

М.В. Максимов, М.Ф. Каназірський, С.О. Кокол. Контроль аксіального офсету ядерного реактора при маневруванні потужністю. Висока надійність та безпека енергоблоку - головні вимоги, які висуваються при експлуатації енергоблоку у маневреному режимі. Запорукою надійної і безпечної експлуатації енергоблоку є стійкість реактора при збуреннях як під час роботи на постійному рівні навантаження, так і в маневреному режимі. Кількісною мірою стійкості реактора $\epsilon$ аксіальний офсет $(\mathrm{AO})$ - технологічна характеристика рівномірності енерговиділення, тому мірою ефективності експлуатації енергоблоку з ВВЕР-1000 є мінімізація відхилення аксіального офсету. Досліджено вплив автоматизованих систем регулювання потужністю енергоблоку в маневреному режимі на аксіальний офсет. Розглянута компромісно-комбінована програма регулювання потужністю реактора, яка передбачає утримання значення аксіального офсету постійним при переведенні енергоблоку з одного рівня потужності на іншій.

Ключові слова: управління аксіальним офсетом, ксенонові коливання, програма регулювання, активна зона реактора, маневрений режим.

М.В. Максимов, М.Ф. Каназирский, Е.А. Кокол. Контроль аксиального офсета ядерного реактора при маневрировании мощностью. Высокая надежность и безопасность энергоблока - основные требования, которые предъявляются при эксплуатации энергоблока в маневренном режиме. Залогом надежной и безопасной эксплуатации энергоблока является устойчивость реактора при возмущениях как во время работы на постоянном уровне нагрузки, так и в маневренном режиме. Количественной мерой устойчивости реактора является аксиальный офсет технологическая характеристика равномерности энерговыделения, поэтому мерой эффективности эксплуатации энергоблока с ВВЭР-1000 является минимизация отклонения аксиального офсета. Исследовано влияние автоматизированных систем регулирования мощностью энергоблока в маневренном режиме на аксиальный офсет. Рассмотрена компромиссно-комбинированная программа регулирования мощностью реактора, которая предполагает удержание значения аксиального офсета постоянным при переводе энергоблока с одного уровня мощности на другой.

Ключевые слова: управление аксиальным офсетом, ксеноновые колебания, программа регулирования, активная зона реактора, маневренный режим.

M.V. Maksimov, N.F. Kanazirskyi, E.A. Kokol. Control of the axial offset in a nuclear reactor at power maneuvering. High reliability and security of power unit are basic requirements when the power unit maneuvering mode operation. The reactor stability under disturbances both at steady load and maneuvering load embodies the guarantees of power unit safe and reliable operation. A quantitative measure of the reactor stability is assessed by the axial offset representing the technological characteristics of energy release uniformity, therefore the axial offset minimum deviation is WWER-1000 operation efficiency measure. The power unit capacity automated control systems' influence on axial offset under maneuvering mode is investigated. Considered is the power unit compromise-combined control program, which maintains a constant axial offset value when power unit switching from one power level to another.

Keywords: axial offset control, xenon oscillations, control program, reactor core, maneuvering mode.

Reviewer Dr. techn. sciences, Prof. Odesa nat. polytechnic univ. Pelykh S.N. 